\title{
Theoretical considerations on the proposed of recovery of purchasing power of the minimum wage in Mexico
}

\author{
Reflexiones teóricas en torno a la propuesta de recuperación del poder \\ de compra del salario mínimo en México
}

Carlos Guerrero de Lizardi*, Leonardo Lomelí Vanegas

Universidad Nacional Autónoma de México, Mexico

Received 3 July 2015; accepted 26 January 2016

Available online 24 May 2017

\begin{abstract}
Regarding the recent proposal made by the Mexico City Government about the recovery of the purchasing power of the minimum wage, some reflections on the theories of production and distribution are proposed. We first review the seminal paper written by Cobb and Douglas (1928). Some obstacles in measuring the marginal factor products, and a pair of inconsistencies between the theories of production and distribution on the one hand, and some exercises of quantifying "productivities" on the other hand, are presented. Finally, a model of imperfect competition, which displays the dispute over income between economic agents, is included. One conclusion is that income distribution does not follow a simple rule, but a bargaining process based on market power in a historical context that provides inertia and in which institutions play a key role. (C) 2017 Universidad Nacional Autónoma de México, Facultad de Contaduría y Administración. This is an open access article under the CC BY-NC-ND license (http://creativecommons.org/licenses/by-nc-nd/4.0/).
\end{abstract}

JEL classification: D20; D30; D63; E64; J30

Keywords: Production and distribution theories; Perfect and imperfect competition models; Political economy of distribution

\section{Resumen}

Tomando como pretexto la reciente propuesta capitalina de recuperación del poder de compra del salario mínimo, se proponen algunas reflexiones en torno a las teorías de la producción y la distribución. En primer lugar, se revisa el documento seminal de Cobb y Douglas (1928). A continuación se presentan

\footnotetext{
* Corresponding author.

E-mail address: cguerrero@economia.unam.mx (C. Guerrero de Lizardi).

Peer Review under the responsibility of Universidad Nacional Autónoma de México.
} 
algunos obstáculos en la medición de los productos marginales de los factores y un par de inconsistencias entre las teorías de la producción y distribución, por un lado, y algunos ejercicios de cuantificación de las «productividades», por otro. Finalmente se retoma un modelo de competencia imperfecta que evidencia la disputa por el ingreso entre los agentes económicos. Una conclusión es que la distribución del ingreso no sigue una regla simple, sino un proceso de regateo basado en el poder de mercado, en un contexto histórico que le proporciona inercia y en el que las instituciones desempeñan un papel clave.

(C) 2017 Universidad Nacional Autónoma de México, Facultad de Contaduría y Administración. Este es un artículo Open Access bajo la licencia CC BY-NC-ND (http://creativecommons.org/licenses/by-nc-nd/4.0/).

Códigos JEL: D20; D30; D63; E64; J30

Palabras clave: Teorías de la producción y la distribución; Modelos de competencia perfecta e imperfecta; Economía política de la distribución

\section{Introduction}

In the month of August 2014 the Government of Mexico City presented a study titled Politica de Recuperación del Salario Mínimo en México y en el Distrito Federal: Propuesta para un Acuerdo Nacional (Policy for the Recovery of the Minimum Wage in Mexico and Mexico City: Proposal for a National Agreement), created by its Economic Cabinet and nine experts with different affiliations (Antonio Azuela, Graciela Irma Bensusán, Gerardo Esquivel, Ariel Rodríguez, Enrique Provencio, Jaime Ros, Pablo Yanes y Raymundo M. Campos). In a study that links minimum wage-and in general the rest of the structure of a country's remunerations - to the so called "labor productivity", it is important not to lose sight of the distinction between the theories of production and the theories of distribution that underlie them. Our intention here is to do just that.

This investigation is structured in five sections. In the first section we do a minimal exposition of the capital's proposal. In the second section we comment, from a theoretical-historical perspective, on the seminal document written by Cobb and Douglas (1928). Without abandoning the neoclassic perspective, in the third section some of the practical obstacles in the measure of the marginal products of the production factors are presented, as well as a pair of inconsistencies between the theories of production and distribution, on the one hand, and some of the quantification exercises of the "productivities" on the other. In the fourth section we come back to an imperfect postKeynesian competition model that determines the number of goods and services available from the amount of employment and the apparent work productivity, and which evidences the conflict for income among the economic agents. The document concludes with some final observations.

\section{Minimum review of the capital's proposal}

Based on a serious effort in the collection of official Mexican statistics and those of other countries, the document presented by the capital's government proposed, in the first place, a set of stylized facts on the trajectory of minimum wage and the "labor productivities" not only for Mexico but for a number of other countries. In this sense, it accurately adopted a historical and international perspective to revise the key variables of its study.

Figs. 1 and 2 reveal the behavior of minimum wage in Mexico and its insufficiency to access the basic products defined by the Consejo Nacional de Evaluación de la Política de Desarrollo Social (National Council for the Evaluation of Social Development Policy) — a public organization that 


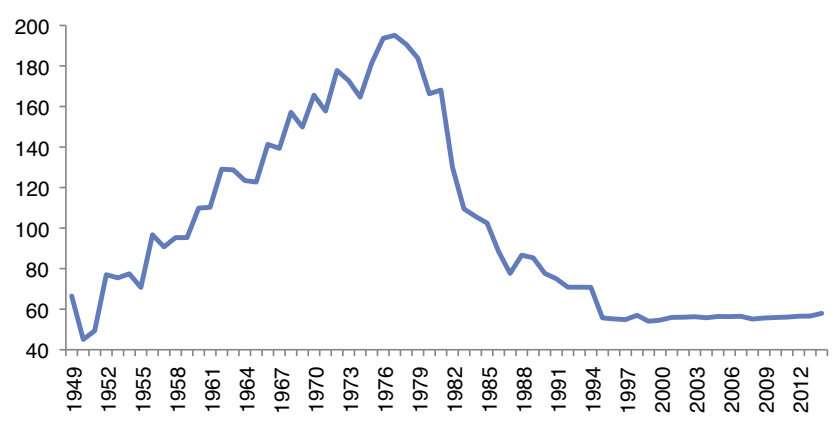

Fig. 1. Real national minimum wage 1949-2014 (pesos per day, 2010=100). Source: Gobierno del Distrito Federal (2014, p. 10).

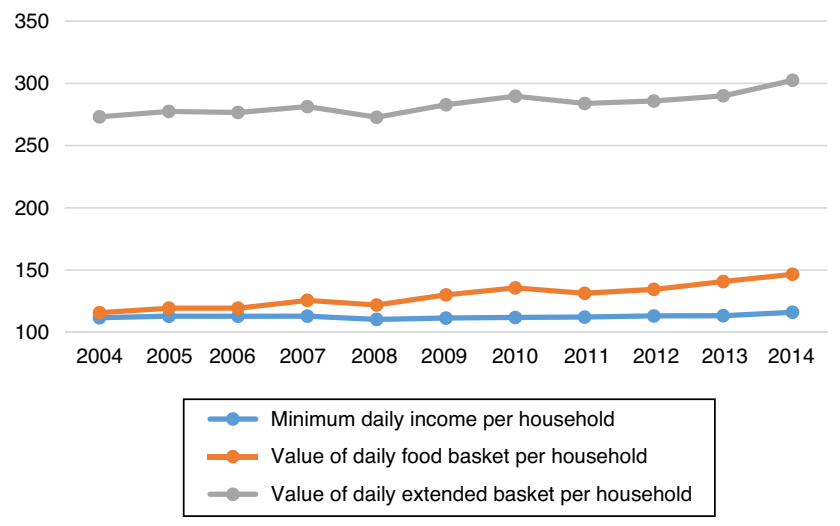

Fig. 2. Value of daily food basket and extended basket per household, and minimum wage 2004-2014 (pesos per day, $2010=100)$.

Source: Gobierno del Distrito Federal (2014, p. 14).

is decentralized from the Federal Public Administration-, according to the official methodology for the measurement of multidimensional poverty.

The loss of purchasing power by the minimum wage of around $75 \%$ in the last three decades is of common knowledge. Put in another perspective, the wage currently paid has remained in the same level for the last forty years. We believe that nobody would dare state that the labor productivity in general, and the one observed in the production of goods in a particular wage, has been stagnant throughout the period that covers the previous Figure, that is, for sixty-six years. Therefore, it should be evident that the crux of the fixation of minimum wage does not lie in the sphere of production, but in that that corresponds to distribution.

The information in Figs. 1 and 2, is enough for the Government of the City of Mexico to plan the following. The first step in the recovery of the purchasing power of the minimum wage would be to increase it by 15.57 pesos per day, or, increase it from 67.29 pesos to 82.86 pesos per day between 2014 and 2015. An increase that is equivalent to the price of a liter of milk per day-assuming a typical family structure of four members, two of which work and obtain a minimum wageit would allow this standard family to achieve a monthly accumulated income that is equal to the value of the monthly basic food products indicated by CONEVAL. In other words, the objective is to establish a minimum wage that guarantees that a family — with two members in the formal sector 


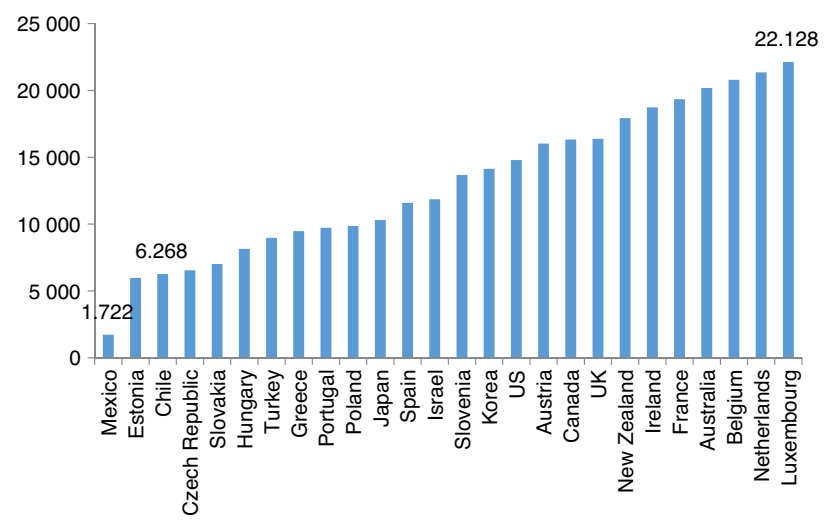

Fig. 3. Real annual minimum wage 2013 (in dollars PPP).

Source: OECD data base.

of the economy-, surpasses the most elemental definition of poverty - called extreme poverty by the same Council; or if preferred, to simply comply with article 123 of the Constitution, which indicates that "the general minimum wage shall be enough to satisfy the normal needs of the head of the family, in the material, social and cultural order, and to provide a statutory education to the children." Let us note that the article cited refers to one minimum wage per family.

Now, the fixed policy of real minimum wage represents a relevant component in the package of economic policies implemented in a country-be they explicit or denied. It is our hypothesis that, in Mexico, the accelerated economic growth with a decrease in poverty, and with a low and controlled inflation during the first post-war decades had, as an energetic component, the great growth of the purchasing power of the workers. In contrast, since the economic uncertainty observed in the middle of the seventies and since the eighties, the national economic policy has rested on the premise that the lower incomes constitute the anchor of inflation as a key instrument of spurious competition in our country (Guerrero, 2011). Thus, we understand the reticence of the majority of economic and financial authorities to even discuss the capital's proposal at first.

Figs. 3 and 4 justify that in the study in review, Mexico is considered not only as an "atypical" but also "inertia eccentric" case on an international level.

At least between 2002 and 2011, and given the number of countries included in the previous Figure, in Mexico not only were some of the lowest minimum wages in the region paid, but it

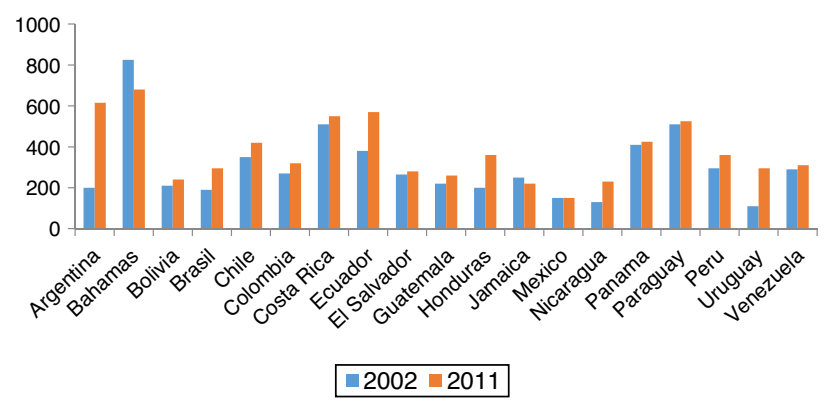

Fig. 4. Monthly real minimum wage 2002 and 2011 (in dollars PPP). Source: OECD data base. 


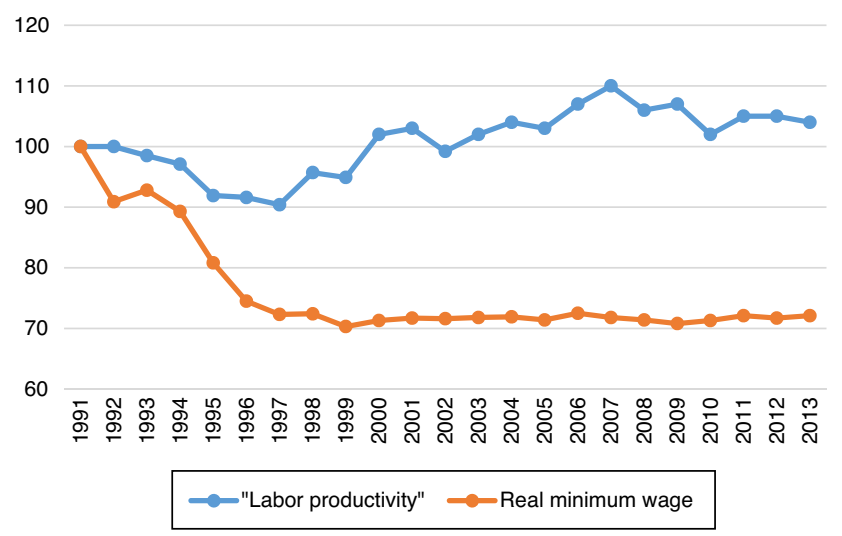

Fig. 5. Real minimum wage and "labor productivity" indexes 1991-2013 (1991=100). Source: OECD data base.

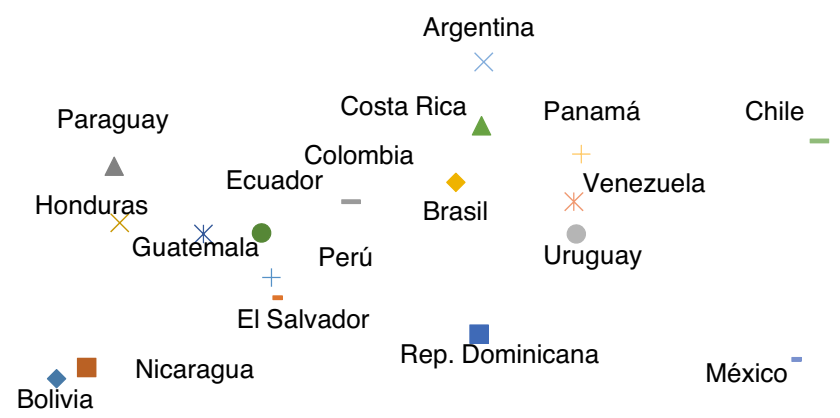

Fig. 6. "Labor Productivity" (in 2005 dollars, horizontal axis) and monthly minimum wages (in current dollars, vertical axis) in Latin America 2010.

Source: OECD data base.

was the only country were the minimum wage froze. Just to add some extra empirical evidence, Figs. 5 and 6 show that there is no allegedly "technical" argument to justify the fall of the real minimum wage, and even less to justify the opposition for a recovery policy of its purchase power.

The proposal for the recovery of the minimum wage contained in the study included diverse theoretical arguments, both microeconomic and macroeconomic, as well as some statistical exercises, and maybe even more importantly, it used a historical and international perspective. In order to give closure to this section, it is worth pointing out that, in a recent Global Wage Report of the International Labor Organization, it is confirmed that "in Mexico, the minimum wage is below the market levels, even for the non-qualified workers" (GDF, 2014, p. 20).

\section{Brief note on Cobb and Douglas (1928)}

At the meeting of the Society of American Economists of 1927, Paul H. Douglas presented a document titled "A theory of production", written in collaboration with Charles Cobb. It is a seminal document because it used the ordinary least squares to estimate a production function for the first time in literature. Jeff Biddle (2012, pp. 225-226) explains what it was normally understood as production and distributions theories in those times, and even more revealing, 
states the lack of consensus among the community of economists with regard to the determinants of distribution:

"In the 1920s, a 'theory of production' was understood to be an explanation of the determinants of the level of output. The amount produced, it was generally agreed, depended upon the level of technological knowledge and the quantities of the factors of production employed... A theory of distribution, on the other hand, explained the determination of the division of output between various members of society. . By the 1920s, the economics profession displayed no consensus regarding the appropriate approach to theorizing about distribution, with approaches based on the marginal productivity principle competing with those rooted in the classical tradition and those emphasizing the ways in which social and economic institutions influenced the bargaining power of various groups."

The dear reader should not doubt the enviable academic environment of the beginning of the last century, in which production — or colloquially speaking, the size of the cake — and distribution were differentiated; as well as the hypothesis on competition or rivals with regard to the size of the "slices of cake". Thus, for example, Summer Slichter-the commentator assigned to discuss the document presented by Douglas - , had a decidedly critical participation regarding the seminal document. Biddle (2012, pp. 225-226) wrote the following in this regard:

"The bulk of his remarks were devoted to detailing problems with the index of fixed capital constructed by Douglas, but his complaints went beyond issues of data quality as he believed the entire project to be wrong-headed. Despite the fact that the marginal productivity theory was not explicitly mentioned in the paper, Slichter thought he could see a hidden agenda, and he did not approve: 'Professors Cobb and Douglas conclude that it has been statistically demonstrated that the relationship between the agents of production on one hand and the volume of output on the other meets the requirements of the marginal productivity hypothesis.' Slichter disputed this specific claim and argued more generally that marginal productivity theory had little to offer as a framework for thinking about distribution."

From the following citation of the last document published by Douglas (1975, p. 914) it is inferred that it was not until the last decade of the fifties when marginalism displaced the rest of the distribution theories, at least in the majority of the community of American economists:

"A considerable body of independent work tends to corroborate the original Cobb-Douglas formula, but, more important, the approximate coincidence of the estimated coefficients with the actual shares received also strengthens the competitive theory of distribution and disproves the Marxian. Many of the original objections have been answered. Some remain. . . I, therefore, still appeal to the younger generation of economists and statisticians for help. A quarter of a century ago, there would have been distinct professional risks in such a venture. The opponents of the production function were eminent, powerful, and determined. No such danger exists today. The times favor such studies. I hope they may be made."

It was thus how, at the end of his career, the author cited published a document in which he consciously related the theories of production and distribution. In that same year, Paul H. Douglas died. It is not possible to understand why he did it, but we want to point out that it is worth reading his work and his memories. As a young doctoral student, he worked as a negotiator between the workers and the owners of companies, and voted for the American Socialist Party, which no longer exists - which, incidentally, dissolved at the beginning of the fifties due to fights among currents. This is how we explain his initial clarity to distinguish between the production and 
distribution theories, but also his subsequent phobia toward Marxist ideas, posed by the so called soviet socialism and its geopolitical block. It suffices as hypothesis to point out that the community of economists got "carried away" with the statistical tool-the ordinary least squares-, and its apparently good results. Professor Lavoie (2008, pp. 2-3) summarizes it in the following manner:

"The word artefact carries several definitions. The most common definition, relevant to science, says that an artefact, or artifact, is a spurious finding caused by faulty procedures. It is a finding that does not really exist but that was created inadvertently by the researcher. In particular, we shall see that neoclassical economists claim to measure output elasticities with respect to capital and labour, whereas in reality they are estimating the profit and wage shares in income. The word artifact is also used in the fantasy literature. In the fantasy and sorcery literature, an artifact is a magical tool with great power, like a magic wand. This definition seems to be just as relevant to the neoclassical production function. Correlation coefficients obtained with regressions of Cobb-Douglas production functions miraculously approach unity, and all the predictions that can be drawn from a model of perfect competition applied to the Cobb-Douglas production function are usually verified, even when we know that these conditions do not hold. In other words, the neoclassical production functions and their derived labour demand functions are not behavioral concepts that can be empirically refuted. Their magical power is enormous!"

\section{Marginalism: after the search of a simple rule}

The starting point is a microeconomic production function:

$$
Y_{i}=f\left(K_{i}, L_{i}\right)
$$

where the level of the product appears on the left side, and on the right side the repertory of capital and the work, and the three variables appear in physical terms. We used the sub-index " $i$ " to make it clear that the production function does not refer to a company, but it reflects the technical conditions of one of its production lines. An implicit assumption is that the organization of the production guarantees the efficient use of both the capital and the labor. Additionally, we assume a scenario without technical changes but only with a simplification mechanism. From Eq. (1) we can immediately calculate the marginal products of the capital and the work independently from one another. It therefore seems that "without further ado", it is possible to go from production, to distribution, to neoclassic. That is not the case, however. Let us go through this matter carefully.

First of all, in its simplest terms, the production function is a truism that says "to produce, the factors of production are needed". In other words, a production function reflects merely an accounting identity between the added value on the one hand, and the capital amounts and work multiplied by their income, respectively, on the other. With regard to this point there is a consensus among the economists. Up to this point, the neoclassic production theory.

Secondly, assuming only a perfect competition scenario-which includes every single one of the markets of goods and services, prominently the ones that correspond to the factors of production-, the salaries and the earnings are fixed from the marginal products of the labor and capital. In this sense, in the Cobb-Douglas production function, we not only find a mathematical esthetic but a genuine shared aspiration by social sciences-and we assume, for the rest of the sciences-, namely, the construction of a simple rule to explain, in this case, the distribution of income. In this regard, under perfect competition, another result that could be even more attractive is that we should not forget that the economy completely makes use of its productive resources. 
Formally put, the marginal product of the labor is defined as:

$$
\frac{\Delta Y_{i}}{\Delta L_{i}}
$$

The increase of the derived product of an hour of additional work or the hiring of an additional worker are put in terms of physical units of " $i$ ", thus in order to obtain the nominal salary you need to multiply (2) by the price of the good or service that was produced.

$$
w_{n o m, i}=\left(\frac{\Delta Y_{i}}{\Delta L_{i}}\right) \times P_{i}
$$

If " $P_{i}$ " is a fixed price under perfect competition, then in the theoretical model we see that the nominal salary and the marginal product of the work are equal magnitudes. ${ }^{1}$ If this is not the case, then the marginality rule is simply broken. And we do not know in what direction or how badly. Under a scenario of imperfect competition and being optimistic, equation (2) is reduced to a "rule of thumb".

At this point accepting without conceding the marginal hypothesis, in third place it must be clear that the real salary determined based on the price of the good or service produced and the real salary determined based on the consumer price index (CPI), are magnitudes that are evidently distinct:

$$
\frac{w_{n o m, i}}{P_{i}} \neq \frac{w_{n o m, i}}{\mathrm{CPI}}
$$

In other words, the aforementioned equation makes it clear that the determination of the increase to the nominal salaries using the CPI growth rate as reference-a rather common operation in the negotiations between the production factors-is a flagrant violation of the "rule" of thumb.

In fourth place, the consumer price index is a Laspeyres index in which the weights of the consumed goods and services is calculated using the expenditure means, i.e., adding the expenditure of each of them and dividing by the total expenditure of the families; incidentally, this aggregation method is known in literature as the "plutocratic" method, in opposition to other methods, e.g., "democratic" (Guerrero, 2014). Kokoski (2003, p. 4), researcher of the Agency of Labor Statistics of our neighboring country in the north, summarizes it as follows: "on one hand the plutocratic aggregation means 'one dollar, one vote', so it treats all dollars of expenditure equally, and on the other the democratic aggregation states 'one household, one vote'."

There are proposals in literature to use other means of aggregation. Prais (1959) proposed, as it has already been mentioned, a democratic focus; the Nobel Arrow (1958) recommended carrying out as many measurements of inflation as the number of deciles; and more recently Pollak (1998) suggested using the median of the expenditure distribution. The core of the matter here is that, using the CPI as reference to determine the salary increases, means assuming that the pattern of bulk consumption of the families, in our case Mexican families, is similar to that observed by the tenth decile, as illustrated by Fig. 7:

\footnotetext{
${ }^{1}$ In the case of the Sistema de Cuentas Nacionales (System of National Accounts) 2003, the INEGI (2011, first section, titled Presentación (Presentation) without page number, and p. 31) informs us that in the Mexican economy, in terms of diversity, twenty-five thousand goods and services were produced, and twelve-thousand products were imported, by customs tariff and at a request level. Simplifying this analysis, e.g., setting aside, if the reader allows, the spatial and temporal dimensions, we can say that we are speaking about thirty-seven thousand markets in which perfect competition is assumed. No more or less.
} 


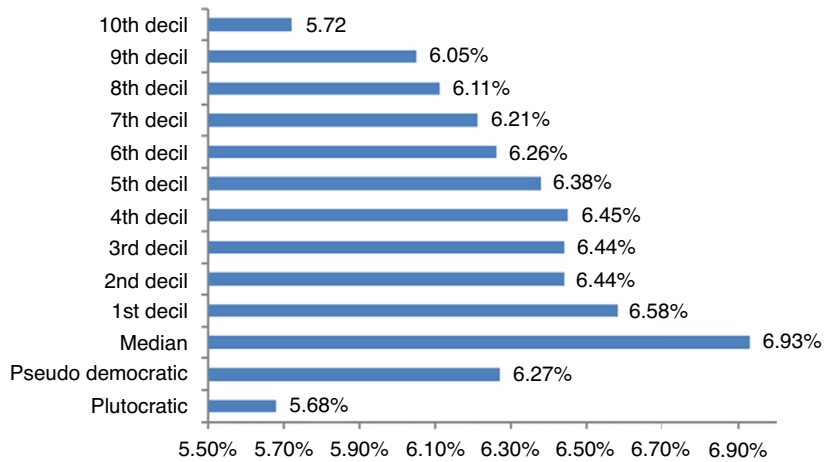

Fig. 7. Alternative consumer price indexes, average growth rates between June, 2H, 2002-2009. Source: Guerrero (2010).

In fifth place, in the production function causality is unidirectional and unequivocal, from the "input" to the "output" evidently, and the marginal products constitute technical coefficients, i.e., constant values in the short-term. However, in empirical studies on the so called "productivities" their pro-cyclical behaviors are worth noting, which represents a senselessness from the canonical theoretical model. We shall only note as examples that in the capital's study there is talk of the "productivity fluctuations per hour", and that in a recent study by the OECD (2012) there is talk of the "cyclical patterns of work and multifactorial productivity". Therefore, it is recognized that the real economies are not scenarios of perfect competition, thus they neither work under full employment nor the production factors obtain their marginal products. If we may, we will thus adopt the Keynesian expression "of closet".

Thinking along the same lines, let us remember that the introduction of the so called "efficiency salaries" represents the tacit rejection of the marginal principle, in the sense that it affirms that the better paid workers will be the most productive. Collaterally, the non-compliance of the assumed efficiency implicit in Eq. (1) is thus recognized.

Finally, we are sure that the attentive reader has observed that we repeatedly place "labor productivity" in quotations - in spite of its common and ordinary use. The heart of the matter is that from the production function what is rigorously obtained-simply dividing (1) by the work factor-is the apparent productivity of the work. Rewriting the production function this way, reveals that the apparent productivity of the work depends on the capital-work relation. Once more, the wrongly called labor productivity — defined by the textbook economists as a condition of the increase of the minimum wage - is revealed not as dependent of individual effort-let us remember once more that an assumption of the model is that the organization of the production guarantees the efficiency in the use of the production factors-, but rather dependent on the capital endowment per work unit.

\section{An imperfect post-Keynesian competition model}

Hereunder we present an alternative theoretical scenario that, we think, helps understand two fundamental facts of any market economy (Guerrero, 2009). The first, based on an accounting identity, notes that the quantity of goods and services available in an economy depends on the quantity of work and its apparent productivity. The second, the distribution of said quantity of goods and services does not follow a simple rule, it is rather the result of a bargaining process 
between the economic agents, in which their market strength plays a key role, in a historical context that provides it with a lot of inertia and in which the institutions represent the backdrop, for good and for bad.

The following group of equations corresponds to an imperfect post-Keynesian competition model, i.e., to an economy where some companies, let us say those dominant in each product line, are "price setters", in the sense that they fix their own profit margin, and the rest "follow the prices". The attentive reader will discover that a good part of this model is based on accounting identities.

We begin with a closed economy. The unitary labor cost is equivalent to the salary cost per product unit:

$$
\frac{W E}{Y}=\frac{W}{L P}
$$

where the apparent labor productivity $(L P)$ is defined as:

$$
L P=\frac{Y}{E}
$$

Following the profit margin rule (add formula), the price is determined as follows:

$$
P=(1+\mu)\left(\frac{W}{L P}\right)
$$

In short, (add formula) depends on the market strength of the leading companies, which is assumed to be relatively stable. Another way to express (7) is:

$$
P=\left(\frac{1}{1-m}\right)\left(\frac{W}{L P}\right)
$$

where

$$
m=\frac{\mu}{(1+\mu)}
$$

Rewriting (8) as:

$$
P=m P+\frac{W}{L P}
$$

That is, the price is broken down into two parts. The first corresponds to the unitary profit margin, and the second to the unitary labor cost that, as we have seen, depends inversely on the apparent labor productivity.

If we divide by the price and multiply by the apparent labor productivity, we arrive at:

$$
L P=m L P+\frac{W}{P}
$$

The aforementioned equation highlights the conflict of the product generated per worker, or in other words, its equality with the sum of the real benefit obtained per contracted worker and the real salary per worker, which represents the limit established by the apparent labor productivity of the economic aspirations of the participants in play. Given the variables contained in the 


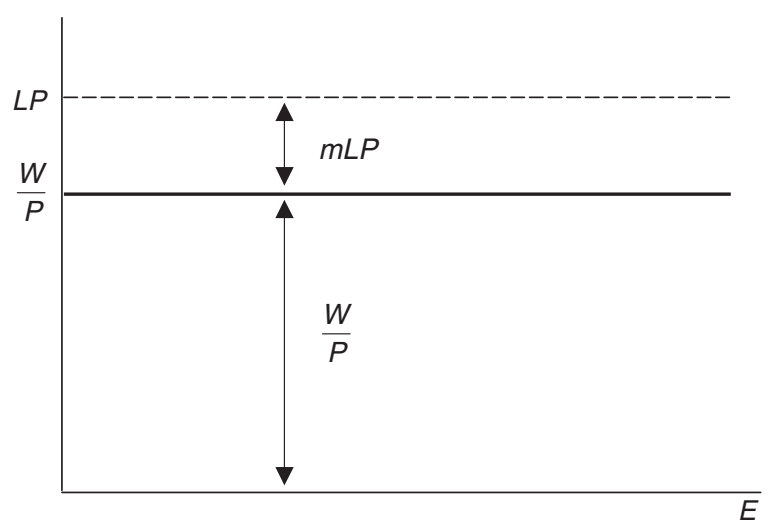

Fig. 8. Determination of real wages in a closed economy.

aforementioned equation, namely, the profit margin, the apparent labor productivity, and the nominal wages, the fixing of the price implies a specific level of real salary.

$$
w=\frac{W}{P}=L P(1-m)
$$

In other words, the aforementioned equation shows that what is "pocketed" is no longer "received" by others, in opposition to the marginal approach (Fig. 8):

In an open economy we have to rewrite (10) in the following manner:

$$
P=m P+\frac{W}{L P}+\frac{P * e}{M P}
$$

The third term represents the unitary cost of the imported inputs in local currency, i.e., $(1 / M P)$ represents the cost, $M P$ its "productivity, and $(P * e)$ the exchange of the external price using the nominal exchange rate. Dividing by the price and using the most common definition of the real exchange rate (add formula), i.e., an increase of theta implies giving more local currency per dollar, or its equivalent, gain competitiveness, and the contrary, we can rewrite (13) in the following manners:

$$
\begin{aligned}
& 1=m+\frac{w}{L P}+\frac{\theta}{M P} \\
& L P=m L P+w+\theta\left(\frac{L P}{M P}\right) \\
& w=L P-m L P-\theta\left(\frac{L P}{M P}\right)
\end{aligned}
$$

Eq. (15) shows that, in the conflict of the product per worker in an open economy, there is a third participant, approximated by the real unitary cost of the imported inputs, and that the satisfaction of the demands of the participants has as a key variable, or objective limit, the apparent labor productivity. For its part, Eq. (16) places the real salary as a residual variable. We believe that this model helps explain the group of stylized facts contained in the first section of this document, i.e., to understand the overall evolution of the minimum wage on the one hand, and of the labor 
productivity, profit margins, and the spurious competitiveness of the Mexican economy on the other.

\section{Conclusions}

As backdrop we have to remember that the reduced economic growth of recent decades is, in good measure, the result of the loss of acquisitive power of salaried workers. The Mexican economy has substituted the stimulus of internal demand for that of external demand creating a dependence, fragility and a carryforward loss never seen before, or in other words, an economic trajectory that needs to be broken if we want to grow more and better. And the poverty and informality levels are expressions of the same salaried policy, i.e., they are phenomena caused by the very economic model implemented since decades back. According to CONEVAL (2013, p. 15): "between 2010 and 2012, the ratio of people in poverty in the country went from 46.1 to 45.5 percent. Although the change was not statistically significant, this implied that, as the result of population growth, the point estimate of the number of people in poverty will go from 52.8 to 53.3 millions of people." And in 2012 according to the INEGI, 19.6 millions of occupied people found themselves in informality, and 29.3 million in the formal economy. Incidentally, in its definition of informality the INEGI does not include the informal who work in the formal sector-thus it can be assumed that there is an underestimation in its figure. From our point of view it is clear that it is necessary to overcome past traumas, and it is essential to implement new economic policies accompanied by new institutional designs, in order to confront the huge national problems in the face of the globalization that operates as global reality.

We recommend having in mind, at all times, the distinction between production and distribution. In the case of the Cobb-Douglas function the aforementioned translates in not losing from sight the assumptions that allow us to establish its simple rule of distribution-among other characteristics of its construction. Strangely enough, something similar occurs in other ideas. For example, the neoclassicals typically connect their theories of production and distribution, the post-Keynesian economists critique the production function-which does not express anything other than an accounting identity - as a means to attack the marginal proposal. And something similar happens with the Marxist economists, they assume that if they manage to build "incontrovertible" empirical evidence regarding the link of the values and prices, then it would prove the Marxist surplus value theory as valid (read their theory on the exploitation of live work). For and every one of the cited schools of thought, i.e., the theoretical validity of a hypothesis, e.g., regarding the sphere of production, does not translate automatically to another hypothesis, e.g., regarding distribution! If preferred, we could say that the aforementioned at least deserves an in-depth debate around the methodology of the science, in particular in economy, and in other social sciences in general-nonexperimental sciences, that is, that require the construction of imperfect simplifications of reality known as models.

The documented presented by the capital's Government is exceptional in many ways. It is an initiative from the political power to jointly build an economic policy, in this case the recuperation of the purchase power of the minimum wage of the workers with the least negotiation power in the market. The subject will seasonally enter and leave public discussion-prior to the intermediate elections of 2015 the public discussion already opened up in our country, and we are sure that it will comprise the subject of public policy before the presidential elections of 2018 — and its success shall depend on the action of several and different economic and political actors. 


\section{References}

Arrow, K. J. (1958). The measurement of price changes. In The relationship of prices to economic stability and growth. pp. 77-87. Joint Economic Committee U.S. Congress, U.S. Government Printing Office.

Biddle, J. (2012). The introduction of the Cobb-Douglas regression. Journal of Economic Perspectives, 26(2), 223-236, http://doi.org/10.1257/jep.26.2.223.

Cobb, C. W., \& Douglas, P. H. (1928). A theory of production. Papers and Proceedings of the Fortieth Annual Meeting of the American Economic Association. American Economic Review, Supplement, 18(1), 139-165.

CONEVAL. (2013). Informe de la Pobreza en México 2012, México.

Douglas, P. H. (1975). The Cobb-Douglas production function once again: its history, its testing, and some new empirical values. Journal of Political Economy, 84(5), 903-916, http://doi.org/10.1086/260489.

Gobierno del Distrito Federal. (2014). Política de Recuperación del Salario Mínimo en México y en el Distrito Federal: Propuesta para un Acuerdo Nacional. Ciudad de México.

Guerrero, C. (2009). Determinantes económicos del salario mínimo en países pequeños y abiertos: una aplicación para Centroamérica. Estudios y Perspectivas, 118. CEPAL.

Guerrero, C. (2010). Alternative consumer price indexes for Mexico. Center for International Development Working Paper (Vol. 42) John F. Kennedy School of Government, Harvard University.

Guerrero, C. (2011). Determinantes económicos de las remuneraciones en las manufacturas mexicanas. Panorama Económico, VI(12), 41-56.

Guerrero, C. (2014). A case of 'No man's land' in economics: the theory of price indexes and its applications. International Journal of Pluralism and Economics Education, 5(2), 144-156.

Kokoski, M. (2003). Alternative consumer price index aggregations: plutocratic and democratic approaches. BLS working paper (Vol. 370).

Lavoie, M. (2008). Neoclassical empirical evidence on employment and production laws as artefact. pp. 9-36. Robinson WP, No. 08-09, apareció también en Economía Informa (Vol. 351).

OECD. (2012). OECD compendium of productivity indicators. OECD Publishing.

Pollak, R. A. (1998). The consumer price index: a research agenda and three proposals? Journal of Economic Perspectives, 12(1), 69-78, http://doi.org/10.1257/jep.12.1.69.

Prais, S. J. (1959). Whose cost of living? The Review of Economic Studies, 26(2), 126-134, http://doi.org/10.2307/2296170. 